\title{
Synthesis of Multi-Substituted Pyrrole Derivatives Through [3+2] Cycloaddition with Tosylmethyl Isocyanides (TosMICs) and Electron-Deficient Compounds
}

\author{
Zhengning Ma ${ }^{1,2}$, Zicheng Ma ${ }^{1,2}$ and Dawei Zhang ${ }^{1, *(1)}$ \\ 1 College of Chemistry, Jilin University, Changchun 130012, China; mazn8215@mails.jlu.edu.cn (Z.M.); \\ mazc8215@mails.jlu.edu.cn (Z.M.) \\ 2 College of Plant Science, Jilin University, Changchun 130062, China \\ * Correspondence: z_dw@jlu.edu.cn; Tel.: +86-431-8783-6471
}

Received: 13 September 2018; Accepted: 10 October 2018; Published: 17 October 2018

check for updates

\begin{abstract}
Pyrrole and its polysubstituted derivatives are important five-membered heterocyclic compounds, which exist alone or as a core framework in many pharmaceutical and natural product structures, some of which have good biological activities. The Van Leusen [3+2] cycloaddition reaction based on tosylmethyl isocyanides (TosMICs) and electron-deficient compounds as a substrate, which has been continuously developed due to its advantages such as operationally simple, easily available starting materials, and broadly range of substrates, is one of the most convenient methods to synthetize pyrrole heterocycles. In this review, we discuss the different types of two carbon synthons in the Van Leusen pyrrole reaction and give a summary of the progress of these synthesis methods in the past two decades.
\end{abstract}

Keywords: pyrrole heterocycles; TosMICs; electron-deficient compounds; Van Leusen pyrrole synthesis; [3+2] cycloaddition

\section{Introduction}

Pyrrole and its polysubstituted derivatives are important five-membered heterocyclic compounds, which exist alone or as a core skeleton in many pharmaceutical and natural product structures, some of them have good bioactivity such as antibacterial [1,2], antifungal [3,4], anti-inflammatory [5,6], antiviral [7], antimalarial [8], anticancer [9,10], antiparasitic [11], etc., and can also be used as enzyme inhibitor in the organism [12,13]. Some typical pyrrole derivative chemical structures and the physiological functions are summarized in the following Table 1.

Since pyrrole and its multi-substituted derivatives play an important role in organic synthesis as well as in biology, syntheses of five-membered heterocyclic pyrrole compounds have always been valued by researchers. Over the last decades, there are many methods for synthesizing pyrrole compounds in laboratory routes [14], and the classical methods include Knorr pyrrole synthesis [15], Paal-Knorr pyrrole synthesis [16], Hantzsch pyrrole synthesis [17], Barton-Zard reaction [18], Van Leusen pyrrole synthesis [19], and Piloty-Robinson pyrrole synthesis [20]. These synthesis methods are summarized in Scheme 1. 
Table 1. Some typical pyrrole derivative chemical structures and the physiological functions.

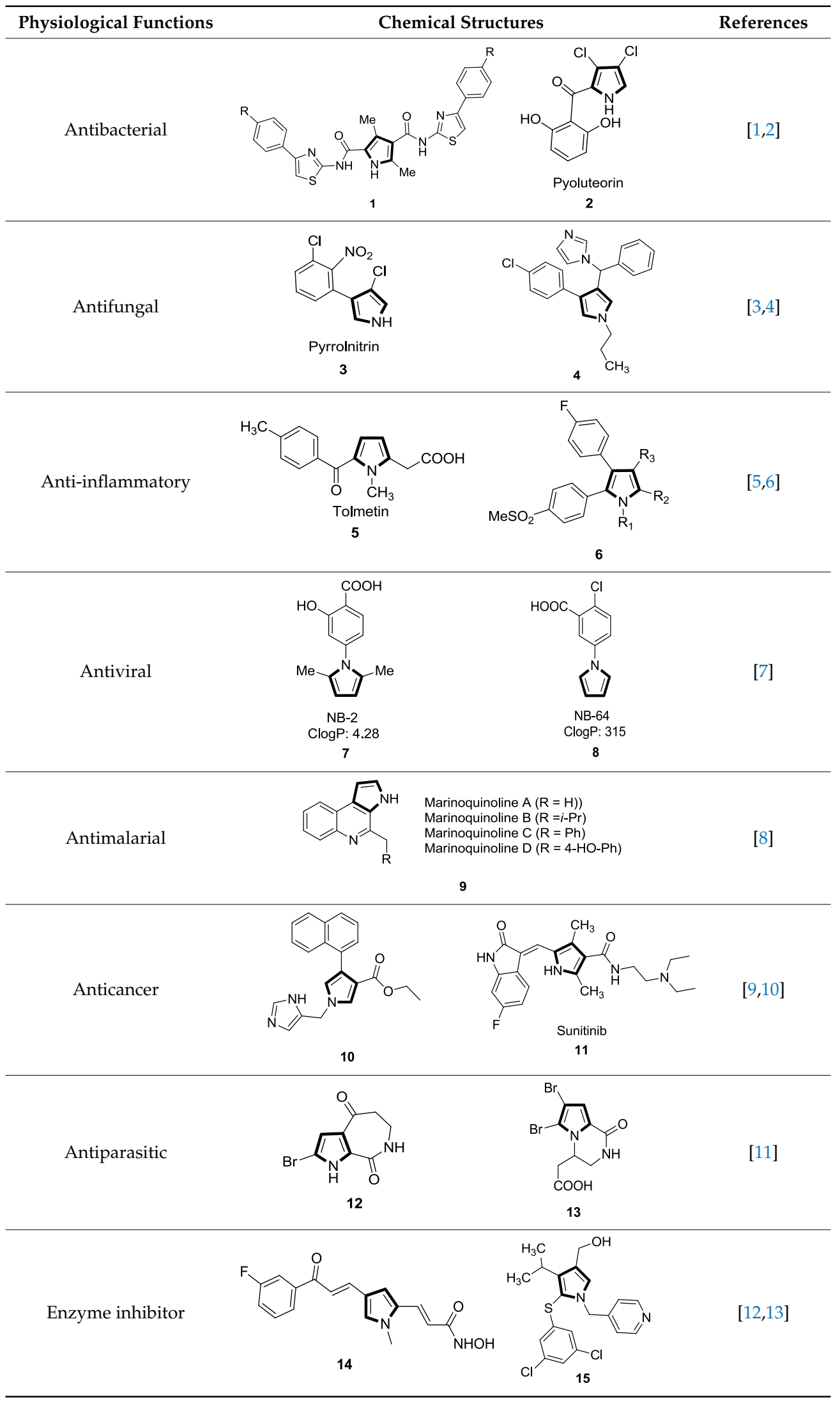




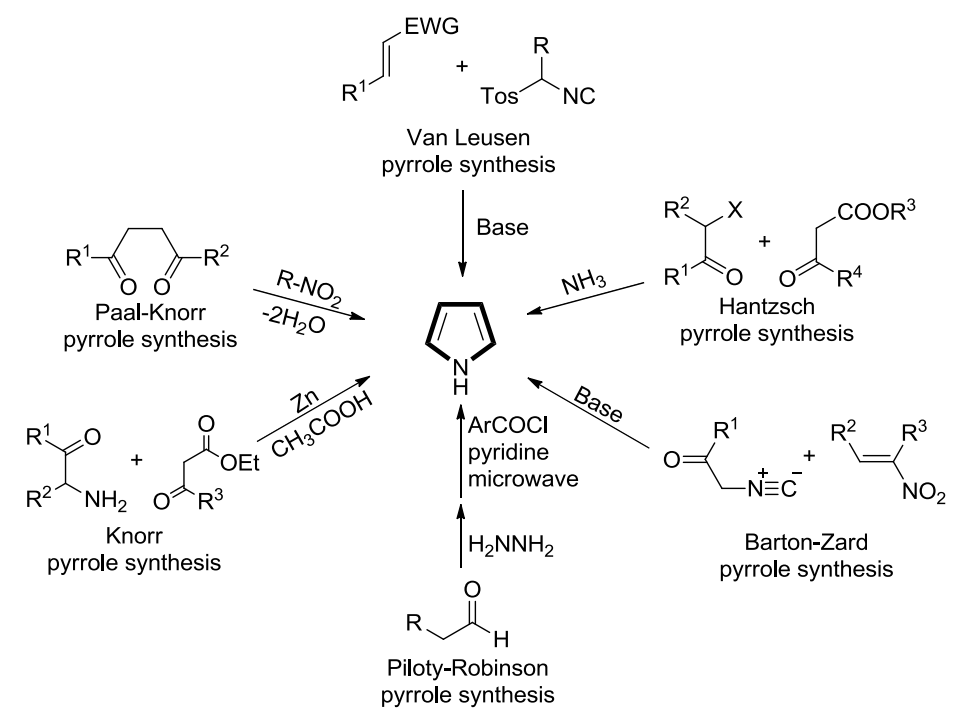

Scheme 1. Typical cycloaddition methods for pyrrole heterocycle and its derivatives.

As shown in Scheme 1, the method for synthesizing pyrrole based on the [3+2] cycloaddition reaction of TosMIC as 3-atom synthon with electron-deficient olefins is also known as the Van Leusen pyrrole synthesis. It was first reported by the Van Leusen et al. in 1972. Van Leusen and co-workers used TosMICs with ester-containing double bond compounds to synthesize a series of 3,4-disubstituted pyrrole compounds under basic conditions [19]. Subsequently, they extended the substrate scope to include electron-withdrawing groups on electron-deficient olefins, such as $\alpha, \beta$-unsaturated cyano, sulfonyl, nitro, and sulfonyl groups, which enriched the structure diversity of the resulting pyrrole compounds [21,22]. Therefore, the Van Leusen [3+2] cycloaddition reaction is one of the most convenient methods to synthetize pyrrole heterocycles, which has been continuously developed over the ensuing years due to its advantages such as operationally simple, easily available starting materials, and broad range of substrates.

TosMIC is a colorless, odorless, stable solid that can be stored at room temperature. It is an important organic synthesis intermediate, and widely used in the synthesis of five-membered nitrogen-containing heterocycles [23]. Under the Van Leusen pyrrole synthesis reaction conditions, TosMIC loses a proton to form a carbanion under the action of a base because of the electron-withdrawing effect of the sulfone and isocyanide. The carbon anion attacks on the $\alpha, \beta$-unsaturated compound, undergoes an intramolecular [3+2] cycloaddition reaction, and causes the leaving of the tosyl group to form the final heterocyclic compound. The mechanism of [3+2] cycloaddition reaction between TosMICs and electron-deficient alkenes to form pyrrole derivatives is shown in Scheme 2.

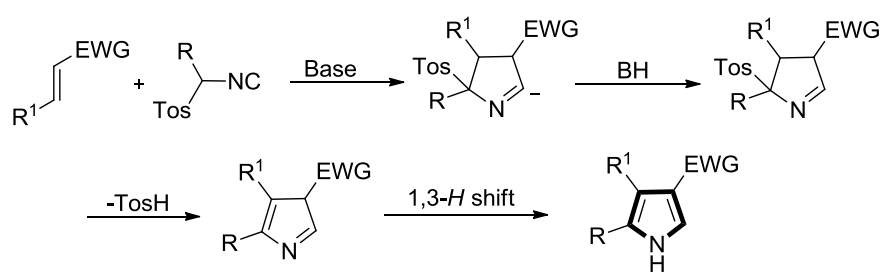

Scheme 2. Mechanism of pyrrole compounds formed by [3+2] cycloaddition between TosMICs and electron-deficient alkenes.

In recent reports, it has been found that this reaction occurs selectively at the position of a less polar double bond. The use of electron-deficient compounds having an electron-withdrawing group and a relatively stable structure, or a solvation effect in the reaction system to stabilize the structure of the electron-deficient compound, can significantly increase the rate and yield of the reactions. 
In this paper, we review the research progress of the synthesis of pyrrole derivatives through the [3+2] cycloaddition reaction between TosMICs and different kinds of 2-carbon synthons based on the Van Leusen pyrrole synthesis method in the past two decades.

\section{Synthesis of Pyrrole Derivatives by [3+2] Cycloaddition of TosMICs with Alkenes}

In 1972, Van Leusen and co-workers firstly reported that TosMICs can react with electron-deficient alkenes under basic conditions to produce 3-substituted pyrrole derivatives [19]. They found that there are [3+2] cycloadditions occurring in alkenes with different electron-withdrawing groups. As shown in Scheme 3, the electron-withdrawing groups may be esters, amides, ketones, nitros, cyanos, aryls, etc. [24-60]. Based on the different types of electron-withdrawing group attached to the alkenes, they are classified and described in order (Scheme 3).

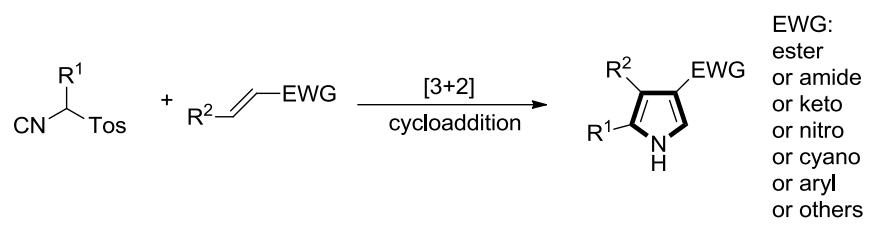

Scheme 3. Synthetic protocols for polysubstituted pyrroles from TosMICs and electron-defect alkenes.

\subsection{Alkenes with an Ester Group}

As early as in the 1990s, Van Leusen and co-workers developed a process in which TosMIC 16 reacts with a Michael acceptor to form 3,4-disubstituted pyrrole compounds 17 or 3-substituted pyrrole compounds 18. This procedure necessarily installs the activating $\mathrm{Z}$ group of the Michael acceptor at the 3-position of the pyrrole ring formed (Scheme 4) [22,24].

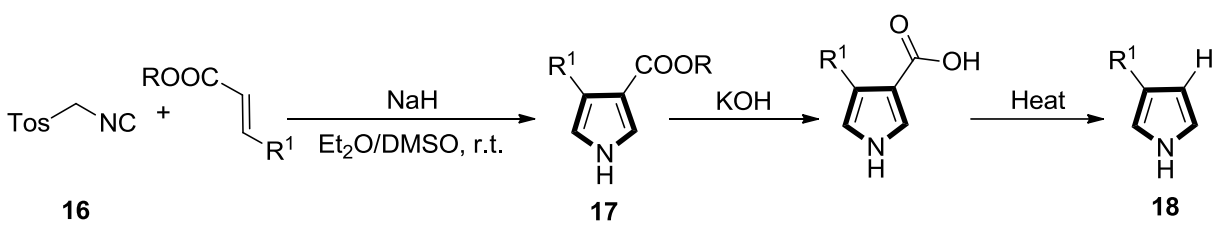

Scheme 4. Synthesis of 3, 4-substituted and 3-disubstituted pyrrole compounds $\mathbf{1 7}$ and 18.

In 1997, the Trudell group described an expeditious method for the synthesis of 3-aryl-substituted pyrroles. The 3-arylpyrroles 22 were prepared in a short reaction sequence from the readily available aryl aldehydes 19. The aldehydes 19 were converted into the corresponding methyl 3-arylacrylate esters 20 using a Wadsworth-Emmons olefination procedure. Treatment of $\mathbf{2 0}$ with TosMIC $\mathbf{1 6}$ afforded the 4-aryl-3-(methoxycarbonyl)-pyrroles 21. Then the ester moieties were hydrolyzed to the corresponding carboxylic acids with excess $\mathrm{KOH}$ in $50 \% \mathrm{MeOH}$. The acid derivatives were then decarboxylated by heating in 2-ethanolamine to give the 3-arylpyrroles 22 in good yield (Scheme 5) [25].

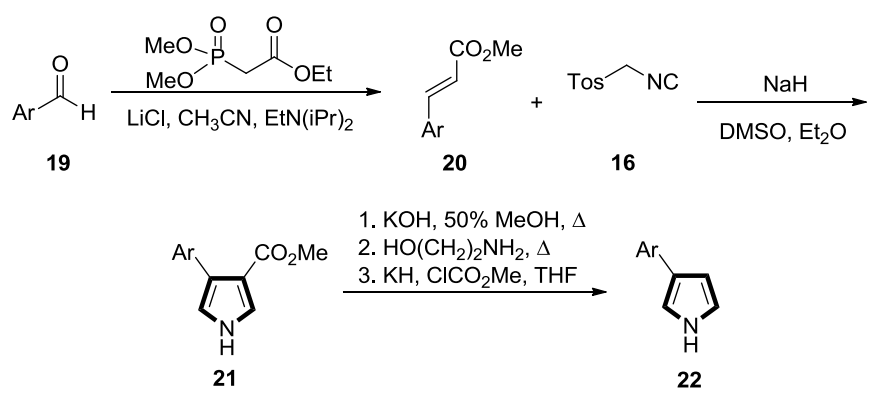

Scheme 5. Synthesis of 3-arylpyrroles 22. 
The electron neutral or electron-deficient aryl vinyl esters such as cinnamic acid esters could be successfully employed in the cyclization reaction. However, the TosMIC $\mathbf{1 6}$ addition reaction with 20 which possessed electron-rich substituents on the aryl ring did not yield the desired pyrroles, but rather gave intractable mixtures.

The next year, Di Santo et al. pioneered the synthesis of $2 H$-pyrrolo[3,4- $b][1,5]$ pyrrolobenzothiazepine 27. They started with tetrabutylammonium fluoride (TBAF)-catalyzed reaction of 2-nitrothiophenol 23 with ethyl 2-propynoate to afford ethyl 3-(2-nitrophenylthio)propenoate 24. Then they performed a transformation of the sulfur derivative into the sulfone analogue by the use of $m$-chloroperbenzoic acid (MCPBA). Afterwards, the novel $E / Z$ mixture 25 was reacted with TosMIC 16 to form ethyl 4-(2-nitrophenylsulfony1)-1H-pyrrole-3-carboxylate 26 as the sole product. $2 H$-pyrrolo[3,4- $b][1,5]$ pyrrolobenzothiazepine 27 can be synthesized by using compound 26 as raw material (Scheme 6) [26].

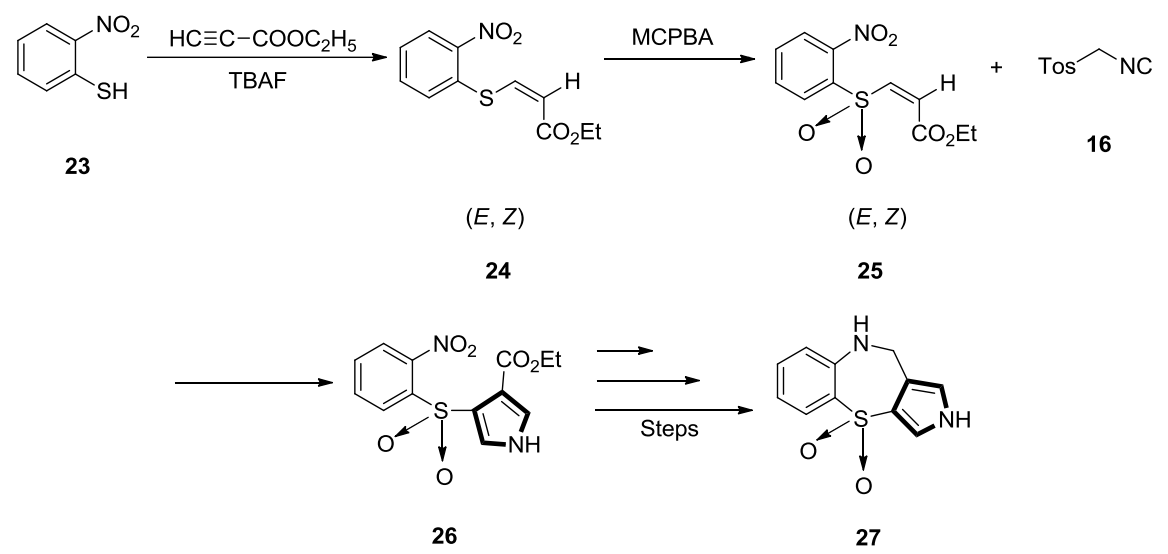

Scheme 6. Synthesis of $2 H$-pyrrolo[3,4-b][1,5]pyrrolobenzothiazepine 27.

In 2007, Krishna's group found that aldehyde 28 on treatment with (ethoxycarbonylmethylene)triphenylphosphorane in refluxing benzene was converted to the $\alpha, \beta$-unsaturated ester 29 (72\%), and treatment of $\mathbf{2 9}$ with potassium salt of TosMIC $\mathbf{1 6}$ afforded the corresponding pyrrole C-nucleosides 30a (36\%) and 30b (32\%) (Scheme 7) [27].

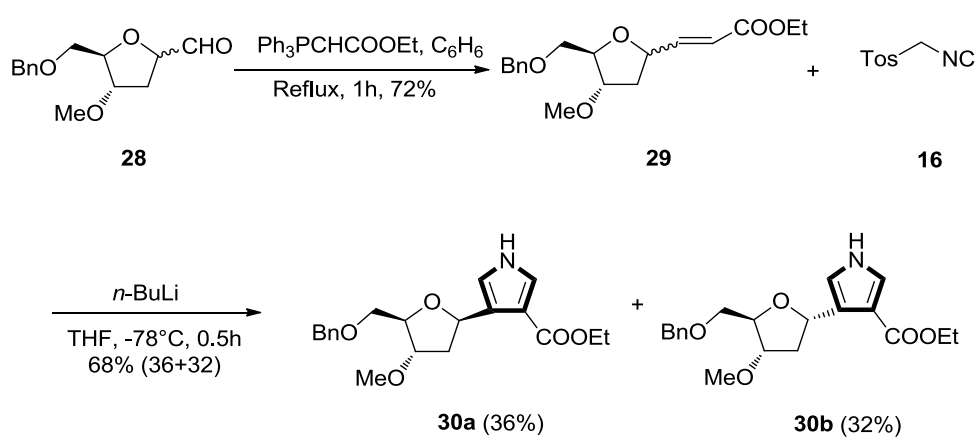

Scheme 7. Synthesis of pyrrole C-nucleosides 30a and 30b.

In 2008, Shin's group developed a synthesis of ethyl 4-substituted-1H-pyrrole-3-carboxylates 33 from aldehyde 31, in which they synthesized $\alpha, \beta$-unsaturated ester 32 from aromatic or aliphatic aldehydes by the Horner-Wadsworth-Emmons reaction and subsequently reacted it with TosMIC 16 in the presence of sodium $t$-amylate in toluene. In this reaction, the solvent, toluene, can be used in both reaction and crystallization, which makes it more practical and greener (Scheme 8) [28]. 


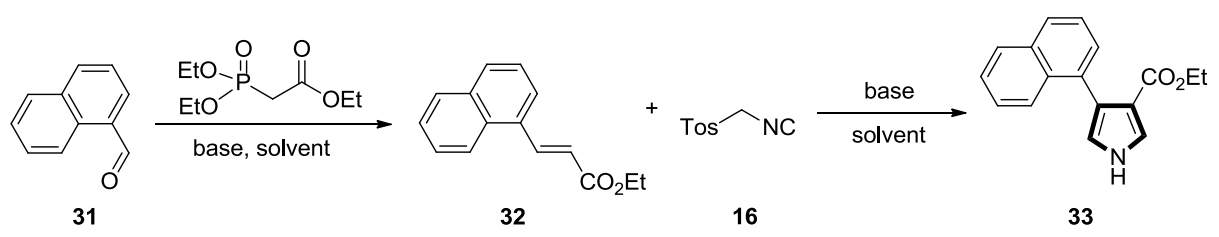

Scheme 8. Synthesis of ethyl 4-substituted-1H-pyrrole-3-carboxylate 33.

Hu's group developed a procedure for the preparation of $N$-arylated 3,4-disubstituted pyrroles 35 from alkenes in the same year. They found that these compounds can be obtained when a mixture of ethyl 3-phenylacrylate 34, TosMIC 16, PhI, CuI, and 1,10-phenanthroline in toluene was treated with 3.0 equivalents of base at $-30{ }^{\circ} \mathrm{C}$ for $10 \mathrm{~min}$ and then the resultant mixture was refluxed until the intermediate was completely exhausted. When a (1:2) mixture of $t$-BuONa to $\mathrm{Cs}_{2} \mathrm{CO}_{3}$ was used as base, 35 was obtained as a single product. In this procedure, $t$-BuONa served as a base for Van Leusen pyrrole synthesis and $\mathrm{Cs}_{2} \mathrm{CO}_{3}$ for the $\mathrm{N}$-arylation, respectively (Scheme 9) [29].

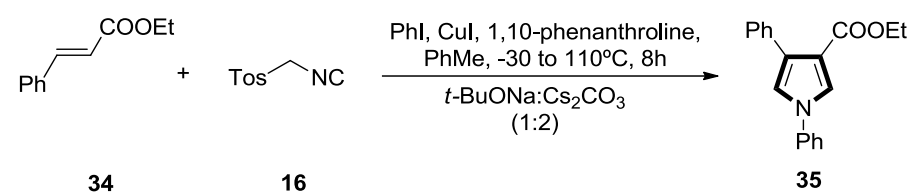

Scheme 9. Synthetic route of $N$-arylated 3,4-disubstituted pyrrole 35.

In 2009, Poulard et al. designed a synthetic route for 3,4-disubstituted pyrrole compounds 40 , in which the 1,2-disubstituted Michael acceptors 38 are prepared by cross-methylation with compounds 36 and 37 that were used to react with TosMIC 16 to obtain 40. Under the same conditions, compounds 41 can be also obtained when the $\mathrm{R}^{2}$ group was the ketone carbonyl-substituted Michael acceptor 39 (Scheme 10) [30].

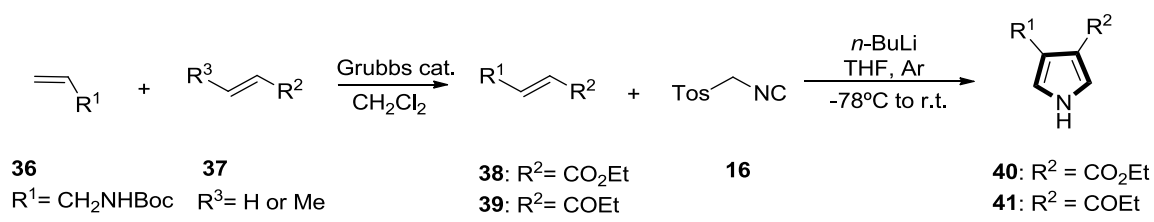

Scheme 10. Synthesis of 3,4-disubstituted pyrrole compounds 40 and 41.

In the same year, the Sánchez-García group reported that 2,2'-bipyrroles compounds 43 were synthesized through the reaction of enesters 42 and TosMIC 16. 2,7,12,17-tetraarylporphycenes 44 can be synthesized by using compounds 43 as raw materials. Porphycenes are of great value in the chemical industry and in biomedicine. During this reaction, there will also be a monopyrrole product formed, but if post-treated with dilute ammonia, the bipyrrole compound can be precipitated in ethyl acetate (Scheme 11) [31].

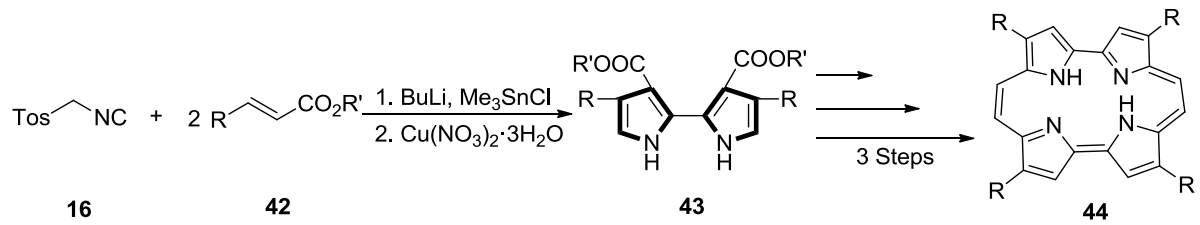

Scheme 11. Synthesis of 2,2'-bipyrrole compounds 43 .

In 2012, Di Santo et al. described the formation of a pyrrole derivative 46 from (E)-ethyl-3-(2-nitrophenyl)acrylate $\mathbf{4 5}$ and TosMIC $\mathbf{1 6}$ under basic conditions. Then, nitro 
reduction and intramolecular cyclization into a lactam were further performed to synthesize 2H-pyrrolo[3,4-c]quinoline compound 47 (Scheme 12) [32].

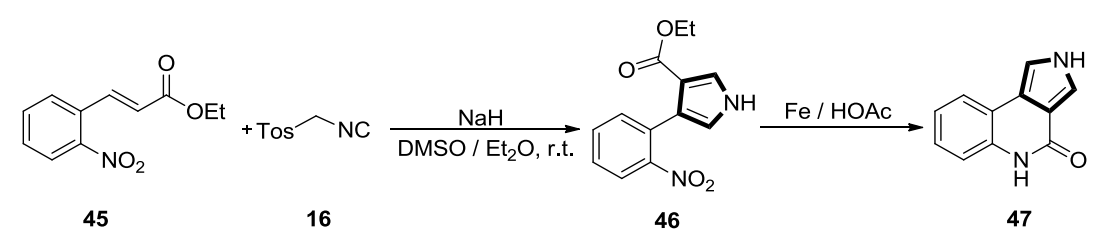

Scheme 12. Synthetic route of pyrrole derivative 47 .

In 2014, the Ji group found that 2-aminoaryl acrylate 48 and TosMIC 16 undergo [3+2] cycloaddition under basic condition and could effectively synthesize pyrrolo[3,4-c]quinolinone 49 or pyrrolo[3,4-c]quinolines 50. It is worth mentioning that the reacted pyrrole intermediate will both undergo an intramolecular condensation reaction of the ester or ketone with the amine during the formation of the quinoline ring. The reactions have good efficiency and practicality, and the yields can reach up to $73 \%$ (Scheme 13) [33].

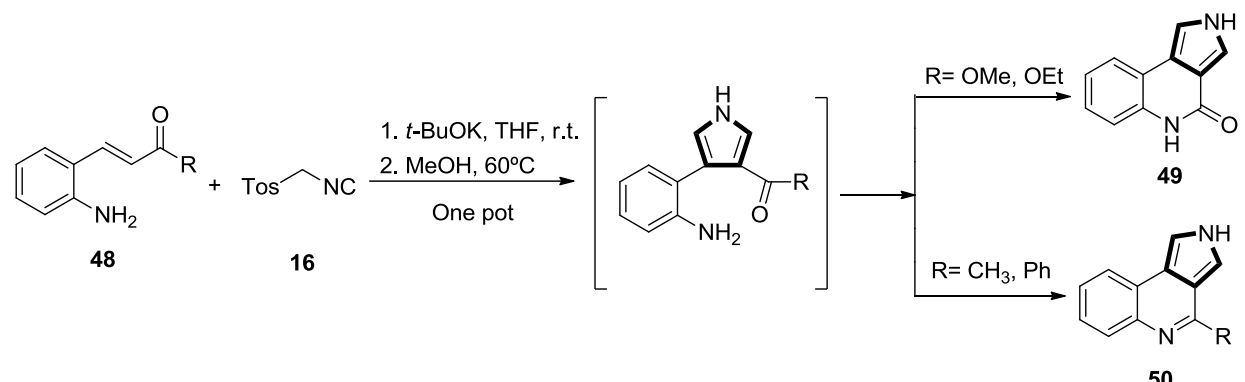

Scheme 13. Synthesis of pyrrolo[3,4-c]quinolinone 49 and pyrrolo[3,4-c]quinolines 50.

In 2015, our group developed an expedient and divergent tandem one-pot synthesis of benz[e]indole derivative $53(79 \%)$ and spiro[indene-1,3'-pyrrole] derivative $54(6 \%)$ from alkyne-tethered chalcones/cinnamates 51 and TosMIC 16. The formation of intermediate 52 in this reaction involves a [3+2] cycloaddition with TosMIC 16 and electron-deficient ester 51 (Scheme 14) [34]. To our knowledge this reaction is the first example of intramolecular electrophilic cyclizations of alkynes with in-situ generated pyrroles.

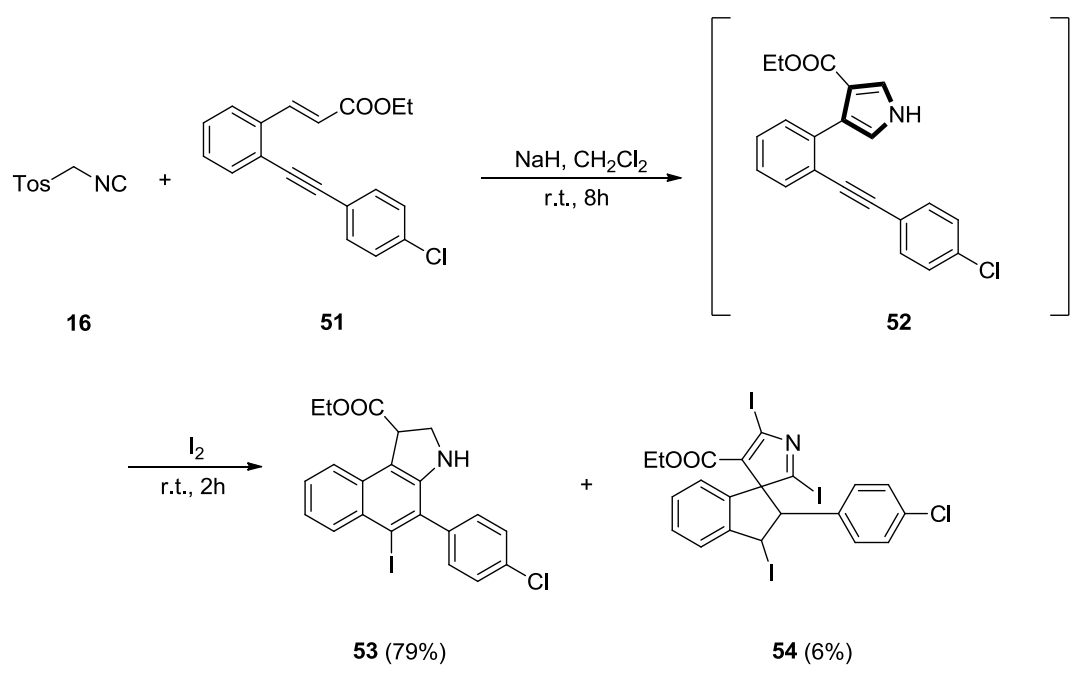

Scheme 14. Synthesis of benz[e]indole derivative 53 and spiro[indene-1,3'-pyrrole] derivative 54. 
In 2018, the Lamberth group reported a new synthesis route of pyrrolocarboxamide compounds 57. They firstly used diethyl maleate 55 as starting material, which was converted with TosMIC 16 into the 3,4-dicarbethoxy-substituted pyrrole 56. Then, after a series of reactions on the substituents, pyrrole carboxamide compound 57 was synthesized (Scheme 15) [35].

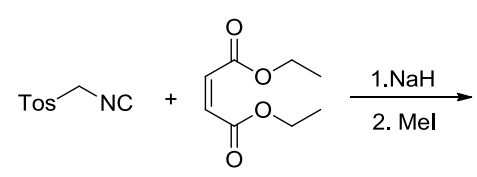

16

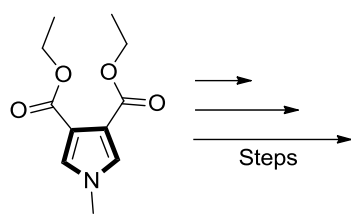

56

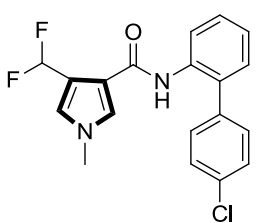

57

Scheme 15. Synthesis of pyrrole carboxamide compound 57.

\subsection{Alkenes with an Amide Group}

Donohoe and co-workers continued to expand the reaction to TosMIC 16 with acrylic acid pyrrolidide 58 to generate two pyrroles in reasonable yields in 1998. The compound was subsequently protected under standard conditions to yield the $N$-Boc pyrrole 60 . Under the similar conditions, $N$-Adoc pyrrole 61 could be obtained from cyclohexyl acrylate 59 and TosMIC 16, respectively (Scheme 16) [36].

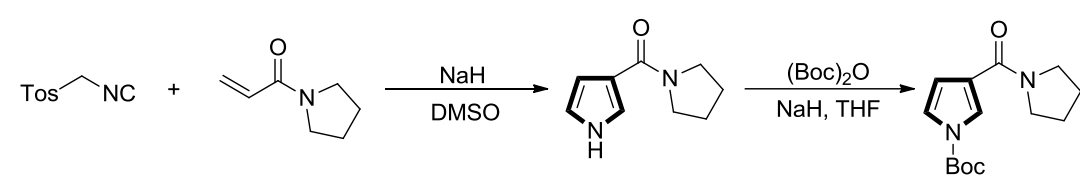

16

58

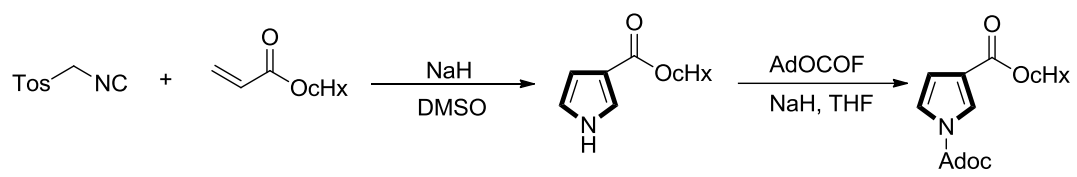

16

59

61

Scheme 16. Synthesis of N-Boc pyrrole 60 or N-Adoc pyrrole 61.

In 2011, Padmavathi et al. condensed cinnamoyl chloride 63 with an aromatic heterocyclic compound 62 containing an amino group to prepare a series of aromatic heterocyclic cinnamic acid amide compounds 64. Then, these electron-deficient alkenes were reacted with TosMIC 16 in the presence of $\mathrm{NaH}, \mathrm{DMSO}$ and diethyl ether to prepare a series of $4^{\prime}$-phenyl-N-(4-heteroaryl-2-yl)-1'H-pyrrole-3'-carboxamide compounds 65 . According to a bioassay, compounds 65 have certain antibacterial activity against Gram-negative bacteria, and most of the compounds have the effect of inhibiting spore germination (Scheme 17) [37].

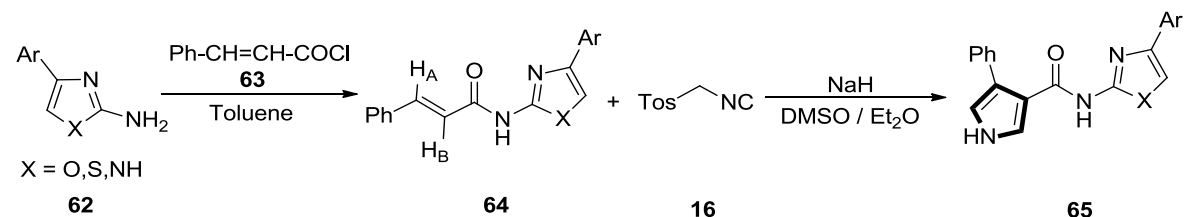

Scheme 17. Synthesis of $4^{\prime}$-phenyl-N-(4-heteroaryl-2-yl)-1'H-pyrrole-3'-carboxamide compounds 65.

In 2017, Adivireddy et. al. developed a synthesis of pyridinylcarbamoylmethyl pyrrolyl compounds 69. In this route, the synthetic intermediate (E)-N-((4-(aryl)-3-cyano-6-(aryl)pyridin2-ylcarbamoyl)methyl)cinnamamide 68 was prepared by the condensation of 2-amino-4,6-diarylpyridine-3-carbonitrile 66 with 2-(cinnamamido)acetic acid 67 in the presence of $o$-(7-azabenzo- 
triazol-1-yl)- $N, N, N, N$-tetramethyluraniumhexafluorophosphate (HATU) and $N, N$-diisopropyl-ethylamine (DIPEA) in DMF under ultrasonication at room temperature. Then occurs the reaction of 68 with TosMIC 16 in the presence of $\mathrm{NaH}$ and in a solvent mixture of ether and dimethylsulfoxide (2:1) produced N-((4-(aryl)-3-cyano-6-(aryl) pyridin-2-ylcarbamoyl)methyl)-4-phenyl-1H-pyrrole-3-carboxamide 69. The bis amido linked aromatized heterocycles pyrrolyl pyridines 69 exhibited excellent radical scavenging activity (Scheme 18) [38].

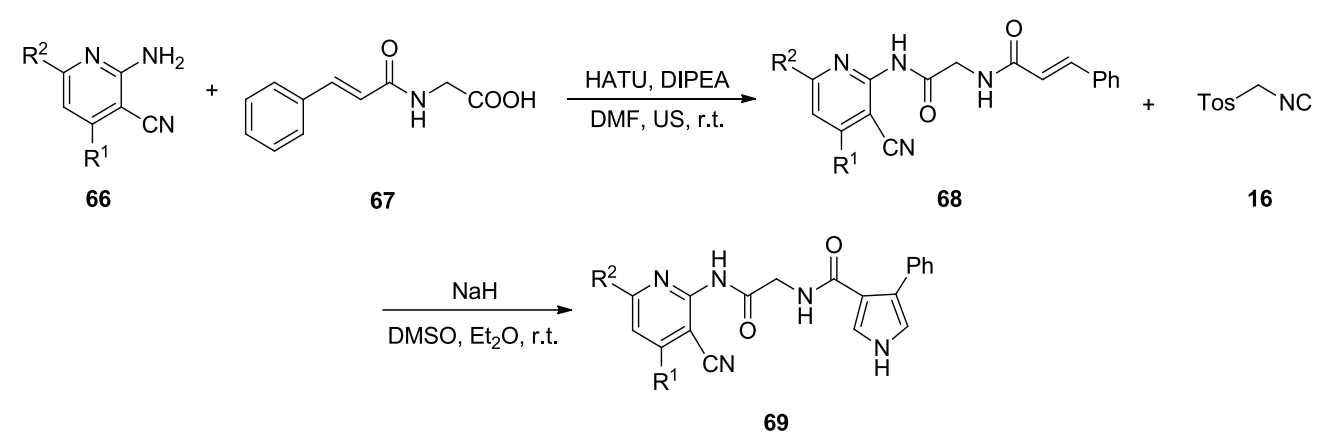

Scheme 18. Synthesis of pyridinylcarbamoylmethyl pyrrolyl compounds 69.

\subsection{Alkenes with a Keto Group}

In 2000, Dannhardt and co-workers reported that 1,3-diarylprop-2-en-1-ones 70 and TosMIC 16 were dissolved in THF as solvent to produce 3-aroyl-4-arylpyrroles 71 in the presence of $\mathrm{NaH}$ at room temperature for $0.5 \mathrm{~h}$. Then compounds 71 were alkylated at the pyrrole nitrogen to afford an N-substituted aryl-aroyl-pyrroles 72 (Scheme 19) [39].

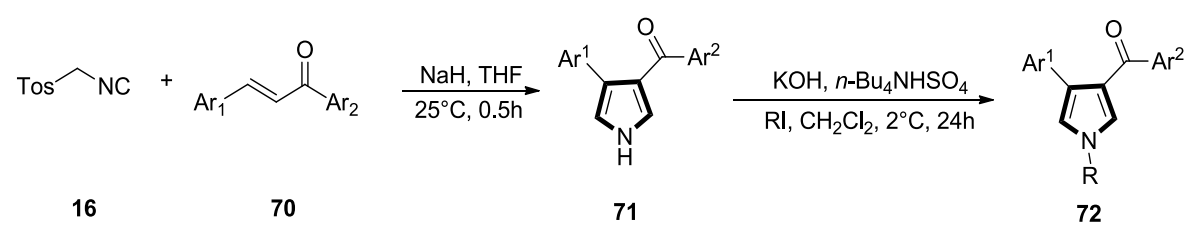

Scheme 19. Synthesis of 3-aroyl-4-arylpyrroles 71 and N-substituted aryl-aroyl-pyrroles 72.

The [3+2] cycloaddition of TosMIC with unsymmetrically substituted divinyl ketones occurs selectively on the less polar double bond. In 2007, the Rao group found that TosMIC 16 and cinnamoylketene dithioacetal 73 can selectively synthesize 3,3-bis(methylthio)-1-(4-aryl-1Hpyrrol-3-yl)prop-2-en-1-one 74 via [3+2] cycloaddition. This reaction occurs selectively on the less polar 4-position ene bond (Scheme 20) [40].

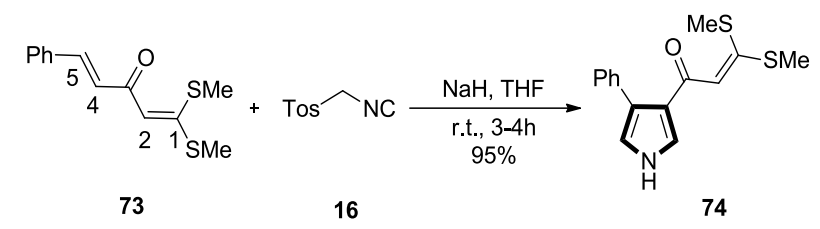

Scheme 20. Synthesis of 3, 3-bis(methylthio)-1-(4-aryl-1H-pyrrol-3-yl)prop-2-en-1-one compound 74.

In the same year, Terzidis et al. reported that chromone-3-carboxaldehydes 75 were allowed to react with equimolar amounts of TosMIC 16 in the presence of DBU, in the aprotic nonpolar solvent THF at room temperature. As a result 2-tosyl-4-(2-hydroxybenzoyl)pyrroles 76 were isolated in good yield (Scheme 21) [41]. 


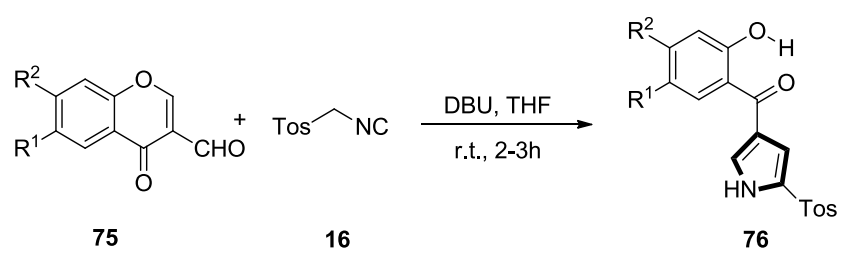

Scheme 21. Synthesis of 2-tosyl-4-(2-hydroxybenzoyl)pyrroles 76.

In 2009, the Pérez group synthetized a series of pyrrole derivatives 78 by using TosMIC 16 with $\alpha, \beta$-unsaturated carbonylic compounds 77, which were obtained through Claisen-Schmidt condensation from the respective acetophenones and benzaldehydes substituted in $m$-position (Scheme 22) [42].<smiles>[R2]c1cccc(/C=C/C(=O)c2cccc(C(=O)c3cccc([R])c3)c2)c1</smiles>

Scheme 22. Synthetic route of pyrrole derivatives 78 .

In 2012, Kelly et al. found that the cyclic $\alpha, \beta$-unsaturated ketone $\mathbf{7 9}$ can be used as a Michael acceptor for 1,3-dipolar cycloaddition to form pyrrole. The 3,4-fused cycloalkanopyrroles 80 were synthesized by reaction of $\mathbf{7 9}$ with TosMIC $\mathbf{1 6}$ and sodium hydride in a 3:1 solution of diethyl ether and dimethyl sulfoxide at room temperature, but the yield of the cyclization appeared to depend on the base-sensitivity of the Michael acceptor (Scheme 23) [43].

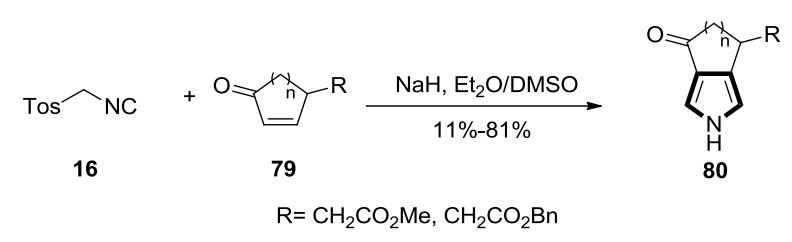

Scheme 23. Synthesis of 3,4-fused cycloalkanopyrroles $\mathbf{8 0}$.

Similar reactions can occur with TosMIC derivatives. In 2013, the Ji group reported the reaction of TosMIC $\mathbf{1 6}$ with (Z)-3-(2-oxo-2-ethylidene)indolin-2-one derivatives 81 to give pyrrole derivatives 82, and developed a simple and convenient synthetic approach to access of $3 H$-pyrrolo[2,3-c]quinolin-4(5H)-one derivatives 83 by the reaction of 81 with functionalized TosMIC derivatives 16 under basic conditions (Scheme 24) [44].

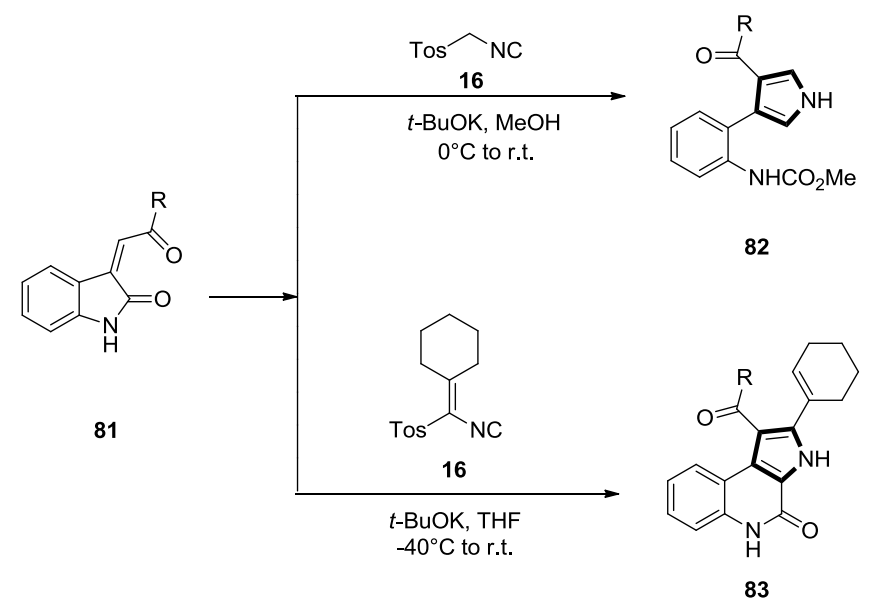

Scheme 24. Synthesis of disubstituted pyrroles 80 and $3 H$-pyrrolo[2,3-c]quinolin-4(5H)-one derivatives 83 . 
In the following year, Ji et al. also discovered a method for synthesizing bridged 3,3'-dipyrrole derivatives 85 by the reaction of dienone derivatives 84 with TosMIC 16. In addition to the classical [3+2] cycloaddition reaction, this reaction also involves $\mathrm{C}-\mathrm{C}$ bond cleavage caused by traces of water in the system. They also captured a spirocyclic intermediate, which is providing a new idea for the study of the construction of bispirocyclic compounds by isonitrile (Scheme 25) [45].

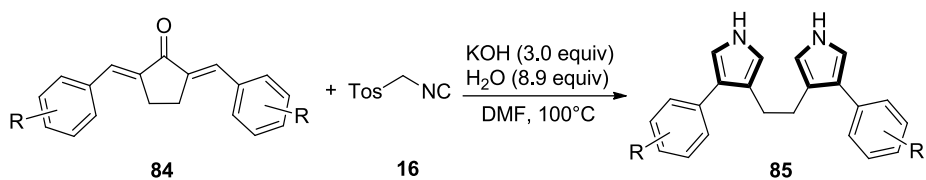

Scheme 25. Synthesis of bridged 3,3'-dipyrrole derivatives 85 .

In 2016, our group described a silver-catalyzed tandem reaction of TosMIC derivatives 16 with 2-methyleneindene-1,3-diones 86 to produce benzo[f]indole-4,9-diones compounds 87 . The reaction undergoes a domino [3+2]-cycloaddition/imidoyl anion cyclization/ring opening of cyclo-propanolate/aromatization and three $\mathrm{C}-\mathrm{C}$ bonds are formed successively. The pyrrole ring is constructed while expanding a carbon atom to the original carbon ring (Scheme 26) [46].

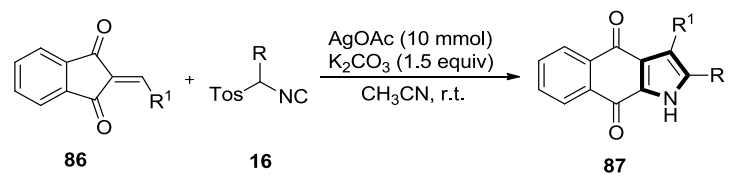

Scheme 26. Synthesis of benzo[f]indole-4,9-diones compounds 87 .

In 2017, Mao and co-workers reported a synthesis of 4-substituted thienyl pyrrole compounds 90 via Vilsmeier-Haack formylation, aldol condensation and Van Leusen pyrrole synthesis using 2-methoxythiophene $\mathbf{8 8}$ as starting material. Compounds $\mathbf{9 0}$ have good selectivity and inhibition to tumor cells (Scheme 27) [47].

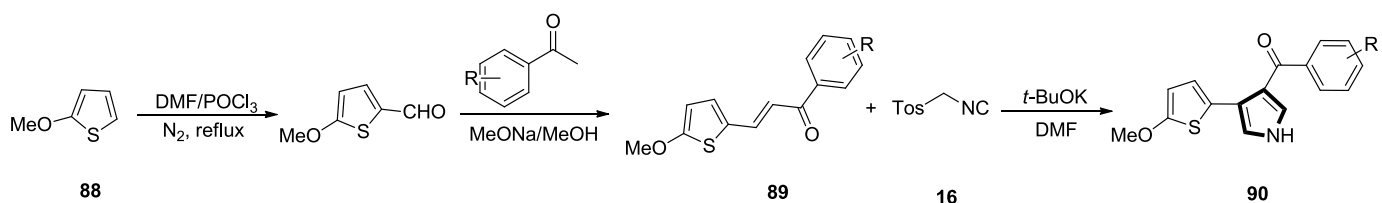

Scheme 27. Synthesis of 4-substituted thienyl pyrrole compounds 90.

In 2017, Shanmugam et al. described that chalcone 91 and TosMIC 16 undergo [3+2] cycloaddition under mild conditions to synthesize 3-aroyl-4-arylpyrrole compounds 92. A new substituted carbamoylpyrrole $\mathbf{9 3}$ exhibiting moderate antibacterial activity against gram-positive bacteria and gram-negative bacteria was then synthesized by a substitution reaction with methyl iodide (Scheme 28) [48].

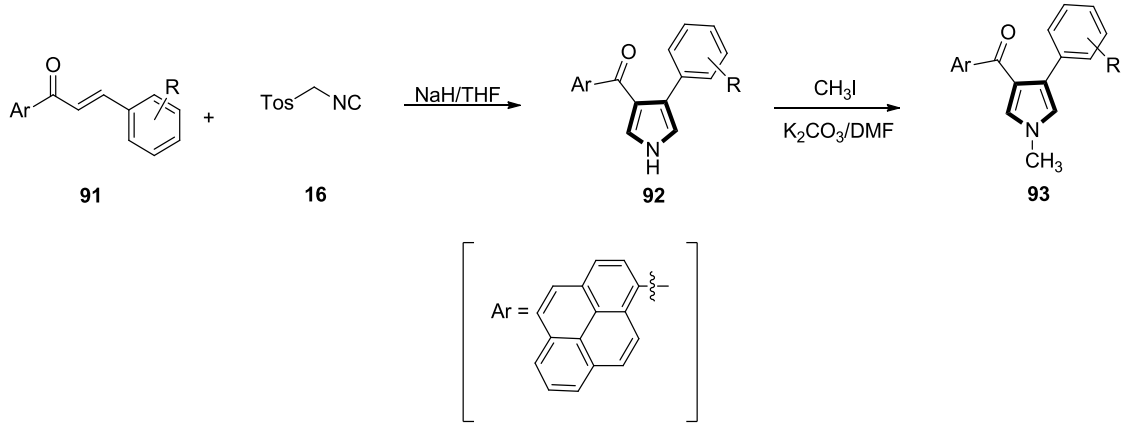

Scheme 28. Synthesis of 3-aroyl-4-arylpyrrole compounds 93. 
Solvation or dynamic solvent effects can affect the rate of [3+2] cycloaddition reaction between TosMIC and aromatic ketones. In 2013, Nair's group discovered a lithium hydroxide mediated 3,4-disubstituted pyrrole synthesis method [49]. As shown in Scheme 29, acetophenone 94 was reacted with benzaldehyde 95 in the presence of $\mathrm{LiOH} \cdot \mathrm{H}_{2} \mathrm{O}$ in ethanol medium to afford 1,3-diphenylprop-2-enone 96 by an aldol condensation between the enolate and the electrophile. Then, TosMIC 16 and an additional equivalent of $\mathrm{LiOH} \cdot \mathrm{H}_{2} \mathrm{O}$ were added to the same system. As the reaction progressed, a white solid precipitated from the reaction medium, the product obtained was filtered, washed with water and ethanol, and characterized as phenyl(4-phenyl-1H-pyrrol-3-yl)methanone 97 . In this reaction system, due to the small size of $\mathrm{Li}^{+}$ ion, $\mathrm{LiOH} \cdot \mathrm{H}_{2} \mathrm{O}$ has obvious covalent character, which slows down the release of $\mathrm{OH}^{-}$. At the same time, a solvation effect occurs in the polar solvent to increase the yield.

A plausible mechanism for the reaction is depicted in Scheme 30. $\mathrm{LiOH} \cdot \mathrm{H}_{2} \mathrm{O}$ abstracts a proton from the methylene group of TosMIC to generate a carbanion which can be stabilized by the sulfonyl group. The intermediate 1,3-dipole undergoes [3+2] cycloaddition reaction to provide the cycloadduct 100. Elimination of lithium $p$-toluenesulfinate under the action of a base to produce a $C-3$ substituted pyrrole derivative 101. Finally, 1,3-hydride shift occurs to afford the product 97 . The $\beta$-substituent of the electrophile ends up at the C-4 position of the pyrrole ring.

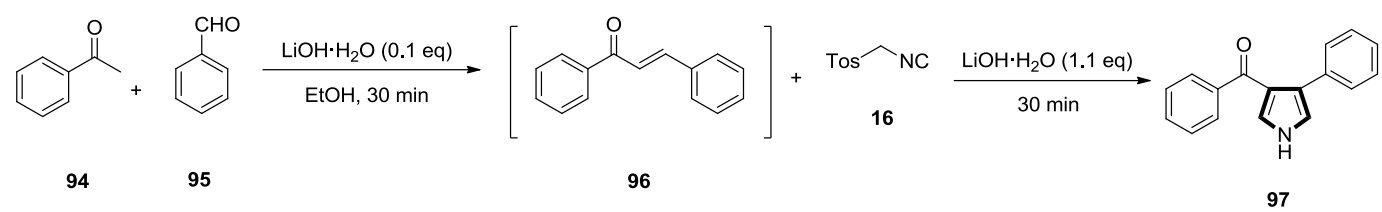

Scheme 29. Synthesis of phenyl(4-phenyl-1H-pyrrol-3-yl)methanone 97.
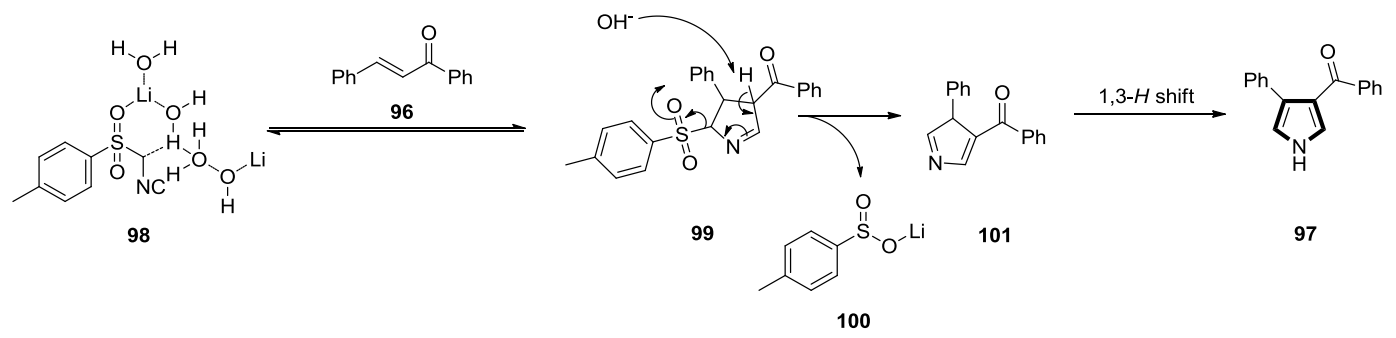

Scheme 30. A plausible mechanism for the [3+2] cycloaddition reaction for TosMIC with $\mathrm{LiOH} \cdot \mathrm{H}_{2} \mathrm{O}$.

In 2016, Nair and co-workers also reported an aroyl-substituted pyrroles 105 synthetic route from phosphonium salt 102 as starting material. The phosphonium salt was neutralized with aqueous $\mathrm{NaOH}$ and extracted with dichloromethane to afford 1-phenyl-2-(triphenyl-phosphoranylidene)ethenone 103. Further the compound was reacted with isobutyraldehyde in dichloromethane to generate the corresponding $\alpha, \beta$-unsaturated ketone 104. Upon completion of the reaction, dichloromethane was evaporated and the reaction mixture was triturated with hexane to remove triphenylphosphine oxide. Moreover, they found that $\mathrm{LiOH} \cdot \mathrm{H}_{2} \mathrm{O}$ gave good yields of the desired product as compared to $\mathrm{NaOH}$ and $\mathrm{KOH}$. This might be due to better coordination power of lithium (Scheme 31) [50].

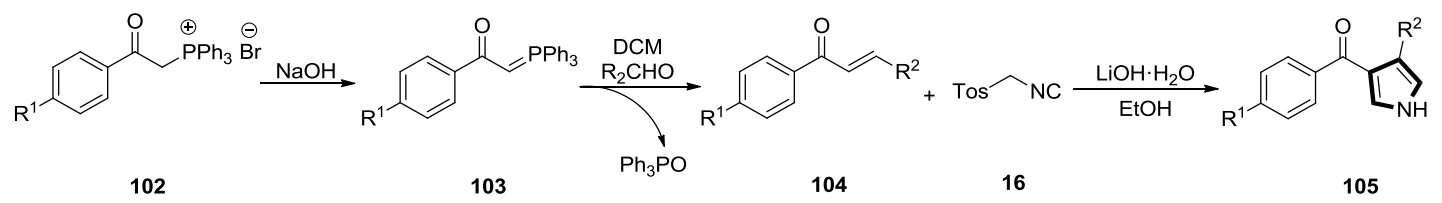

Scheme 31. Synthesis of aroyl-substituted pyrroles 105.

Multi-component Van Leusen pyrrole synthesis can also occur in alkenes with aromatic ketones. In 2014, the Shanmugam research group found that cinnamoylketene dithioacetal 106 undergo 
multi-component cycloaddition with TosMIC 16, guanidine nitrate 107 and alkyl alcohol 108 in the presence of $\mathrm{NaH} / \mathrm{THF}$ to furnish the target 6-pyrrolylpyrimidines 109 in excellent yields of 70-97\% (Scheme 32) [51]. Because of the electron donating characteristics of the two methyl sulfanyl groups and the structural features of $\alpha, \beta$-unsaturated carbonyl group, the arylvinyl double bond is more polarized than the ketene acetal double bond, which causes TosMIC $\mathbf{1 6}$ to selectively react at the arylvinyl double bond.

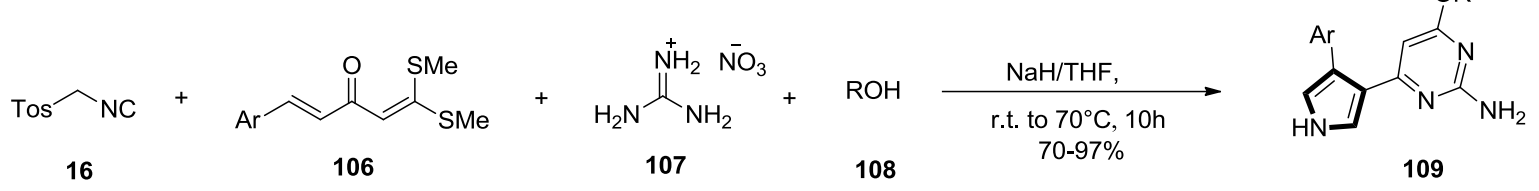

Scheme 32. Synthesis of 6-pyrrolylpyrimidines 109.

\subsection{Alkenes with a Nitro Group}

In 2009, Xiaoqi Yu and co-workers reported that 4(3)-substituted 3(4)-nitro-1H-pyrrole 111 can be synthesized from nitroene $\mathbf{1 1 0}$ and TosMIC $\mathbf{1 6}$ in the presence of the ionic liquid 1-butyl-3-methylimidazolium bromide ([bmIm]Br). This reaction can be widely applied to aromatic, aliphatic or heterocyclic substituted nitroolefins, and the recovered ionic liquid can be repeatedly used as a solvent without significantly reducing the yield (Scheme 33) [52].

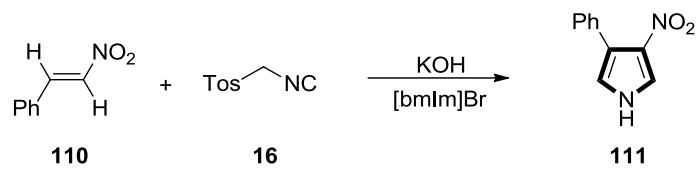

Scheme 33. Synthesis of 4(3)-substituted 3(4)-niropyrrole 111.

\subsection{Alkenes with a Cyano Group}

In 2012, the Yongping Yu group reported that two equivalents of a cyano-substituted trisubstituted alkene 112 and TosMIC 16 were dissolved in anhydrous acetonitrile as a solvent and reacted in the presence of $\mathrm{NaH}$ at room temperature for $3 \mathrm{~h}$ to form disubstituted pyrrole derivatives 113. And the 1,3'-bipyrrole 114 is obtained if the reaction time is extended to $12 \mathrm{~h}$ (Scheme 34) [53,54]. In the experiments, researchers also found that when keto and ester groups are simultaneously present in alkenes, due to the higher reactivity, keto group can be eliminated more easily than ester groups alone. In addition, group with larger steric hindrance can reduce the reactivity when they are present on alkenes.

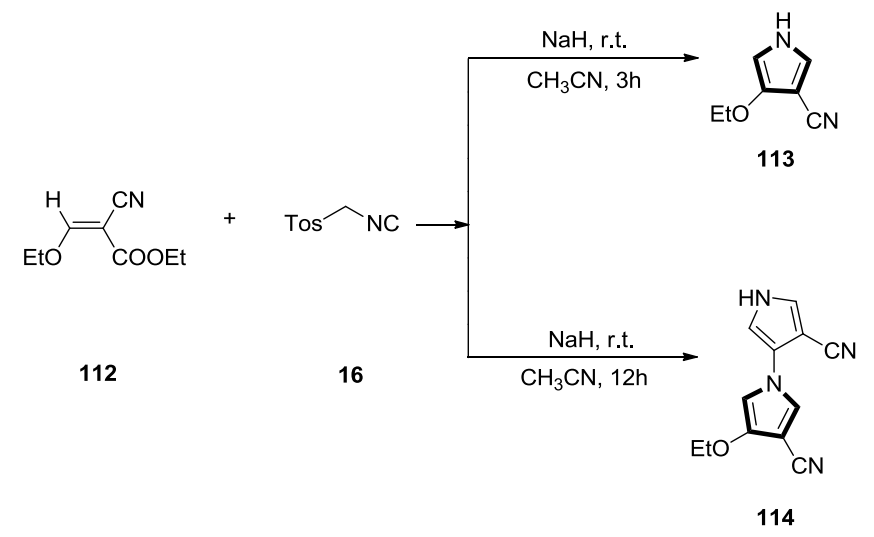

Scheme 34. Synthesis route of 3,4-disubstituted pyrrole derivatives 113 and 1,3'-bipyrrole compound 114. 


\subsection{Alkenes with an Aryl Group}

In 2002, Smith and co-workers developed a method for the one-step synthesis of 3-aryl and 3,4-diarylpyrroles 116 with good yields by readily available aryl or diaryl alkenes 115 with TosMIC 16 (Scheme 35) [55]. They found that the stronger the electron-withdrawing ability of the aryl group attached to the alkene in the substrate, the lower the temperature required for the reaction, the shorter the reaction time, and the higher yield. At the same time, the steric hindrance of the aryl group will act as a deterrent to the reaction. This phenomenon is particularly evident when the aryl group is ortho-substituted.

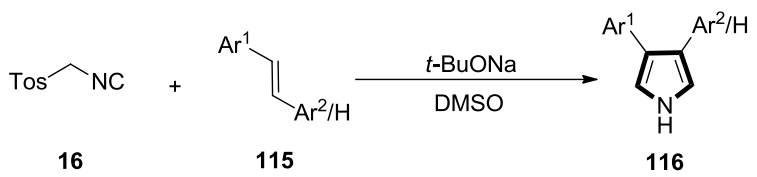

Scheme 35. Synthesis of 3-aryl and 3,4-diaryl-(1H)-pyrroles 116.

\subsection{Other Alkene Synthons}

Magnus et al. reported the effect of metal ion on the conjugate addition of TosMIC $\mathbf{1 6}$ anions to ethyl sorbate 117 in 1987. The sodium salt of TosMIC 16 in DMSO:ether reacted with $\mathbf{1 1 7}$ to afford pyrrole 118 (pathway a) in 80\% yield, whereas the lithium salt of TosMIC 16 in THF afforded the addition adduct 119 in 61\% yield (pathway b) (Scheme 36, left) [56]. On the basis of the research, Ganem and co-workers reported that condensation of $\mathbf{1 1 7}$ with the sodium anion of TosMIC in DMSO: ether gave regioisomers 120 in 1997 . While using $\mathrm{LiN}(\mathrm{TMS})_{2}$ in $\mathrm{THF}$ at $-78^{\circ} \mathrm{C}$, pyrrole derivate $\mathbf{1 2 1}$ was obtained as the only detectable product. The combination of more polar solvent and more highly dissociated anion favored reaction at the terminally polarized $\delta$-position of dienoate 117 , leading to the desired 1,6-addition product (Scheme 36, right) [57].

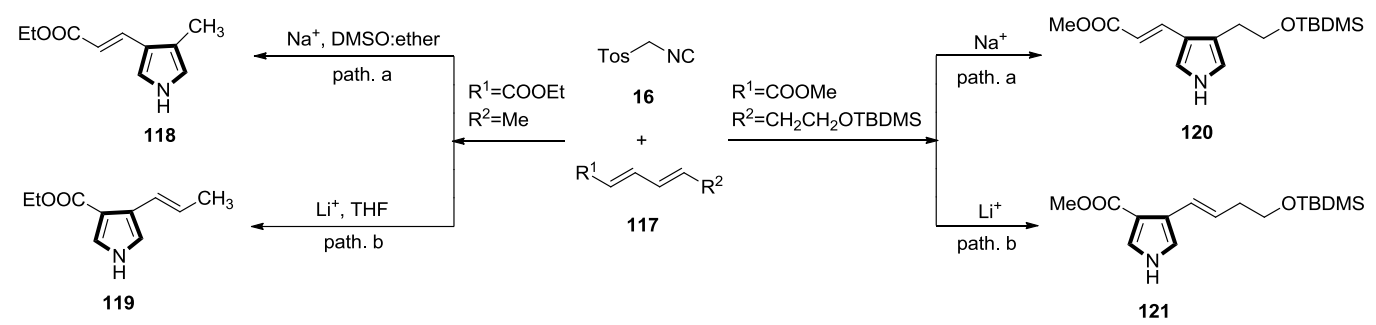

Scheme 36. The effect of metal ion on the conjugate addition of TosMIC 16 anions to ethyl sorbate $\mathbf{1 1 7 .}$

Quinone can be also used for the Van Leusen pyrrole synthesis. In 1996, Di Santo et al. reported a synthesis of $2 \mathrm{H}$-benz[f]isoindole-4,9-dione $\mathbf{1 2 3}$ from TosMIC $\mathbf{1 6}$ that reacts with Michael acceptor 1,4-naphthoquinone 122. $\mathrm{N}$-Methylation of the latter compound with iodomethane in the presence of anhydrous potassium carbonate afforded 2-methyl-2H-benz[f]isoindole-4,9-dione 124 (Scheme 37) [58].

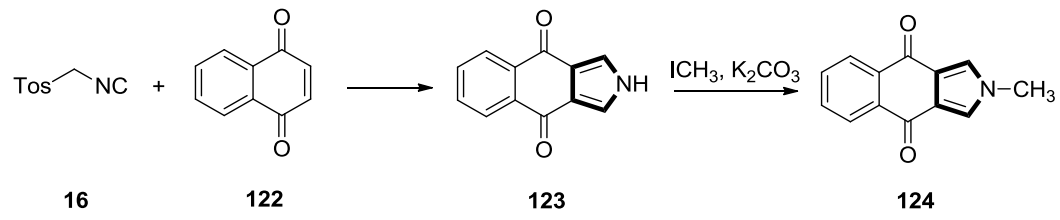

Scheme 37. Synthesis of 2-methyl-2H-benz[f]isoindole-4,9-dione 124.

In 2012, Yongping Yu and co-workers reported synthesis of polysubstituted pyrroles 126 from TosMIC 16 and vinyl azides 125 under mild conditions in the presence of base (Scheme 38) [59]. Additionally, they developed a Van Leusen three-component reaction as a synthesis of 2,3,4-trisubstituted pyrrole 129, where a mixture of 3-nitrobenzaldehyde 127 and ethyl 2-azidoacetate 
128 was stirred under the Knoevenagel condensation conditions using $\mathrm{NaH}$ as the base for $2 \mathrm{~h}$ at $-15^{\circ} \mathrm{C}$, followed by addition of TosMIC 16. The reaction mixture was then stirred at room temperature for $24 \mathrm{~h}$ to give the desired product 129 (Scheme 39) [59].

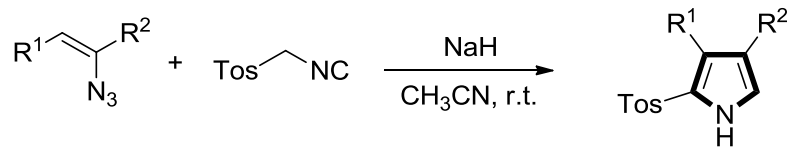

$$
\begin{aligned}
& 125 \quad 16 \quad 126
\end{aligned}
$$

Scheme 38. Synthesis of polysubstituted pyrroles 126.

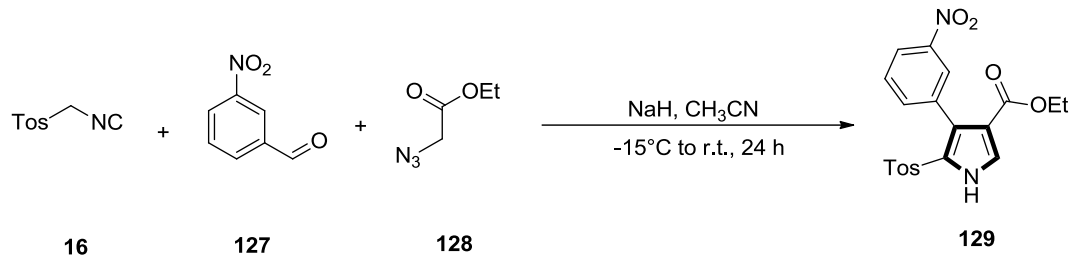

Scheme 39. Synthesis of 2,3,4-trisubstituted pyrrole 129.

In 2017, our research group discovered that TosMIC 16 can undergo a [3+2] cycloaddition reaction with a styrylisoxazole compounds $\mathbf{1 3 0}$ to construct a series of 3-isoxazole disubstituted pyrrole derivatives 131 (Scheme 40) [60]. Under the same optimized reaction condition, the synthesis of the 3-isoxazole trisubstituted pyrrole derivatives 132 was achieved by using the TosMIC derivatives 16 (Scheme 41) [60]. This transformation is operationally simple, high-yielding, and displays broad substrate scope.

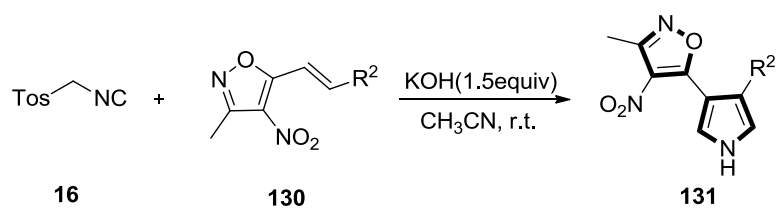

Scheme 40. Synthesis of 3-isoxazole disubstituted pyrroles derivatives 131.

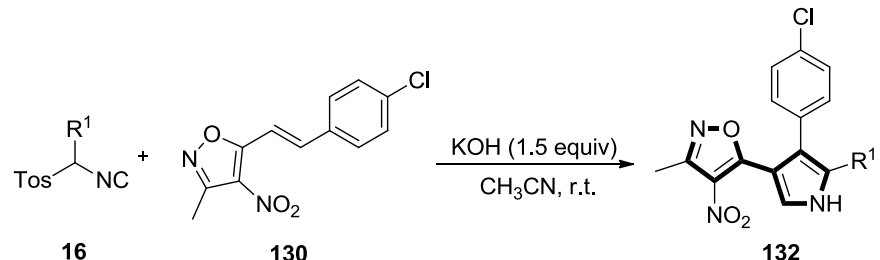

Scheme 41. Synthesis of 3-isoxazole trisubstituted pyrrole derivatives 132.

\section{Synthesis of Pyrrole Derivatives by [3+2] Cycloaddition of TosMICs with Alkynes}

Similar to alkenes, alkynes can also undergo [3+2] cycloaddition with TosMIC to synthesize pyrrole derivatives. As early as in 1979, Saikachi and co-workers found that acetylene ester 133 (2 equiv each) and TosMIC 16 can produce 2,3,4-trisubstituted pyrrole compounds 134 in the presence of DBU. The 1,2,3,4-tetrasubstituted pyrrole compounds 135 can be synthesized by another one-step addition reaction (Scheme 42) [61]. 


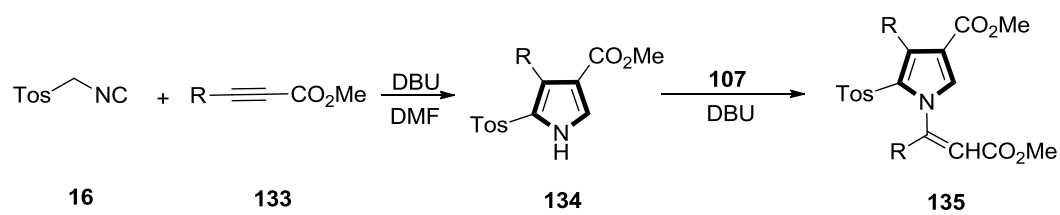

Scheme 42. Synthesis of 2,3,4-trisubstituted pyrrole derivatives 134 and 1,2,3,4-tetrasubstituted pyrrole derivatives 135 .

In 2006, Alizadeh et al. found that dialkyl acetylenedicarboxylates 136 react with TosMIC $\mathbf{1 6}$ in the presence of $\mathrm{Ph}_{3} \mathrm{P}$ to form dialkyl 2-[(4-methylphenyl)sulfonyl]-1H-pyrrole-3,4-dicarboxylates 137. In this reaction, the nucleophilic addition of $\mathrm{Ph}_{3} \mathrm{P}$ to the acetylenic esters further increases the reactivity of the substrate as an electron-withdrawing group (Scheme 43) [62].

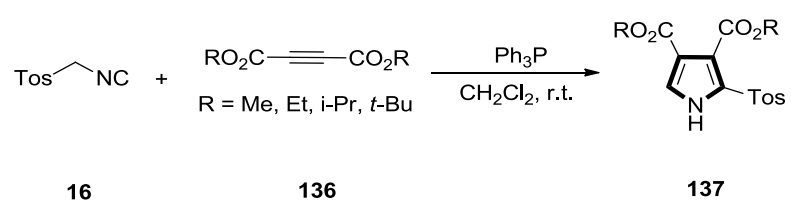

Scheme 43. Synthesis of 2,3,4-trisubstituted pyrrole derivatives 137.

In 2011, the Adib group developed a protocol that is different with respect to the common shortcomings such as long reaction time, low yield, expensive raw materials, and harsh reaction conditions. A mixture of TosMIC 16, and a dialkyl acetylenedicarboxylate 138, in the presence of a catalytic amount of 1-methylimidazole 139 undergoes a smooth addition reaction in anhydrous $\mathrm{CH}_{2} \mathrm{Cl}_{2}$ at room temperature to afford 2,3,4-trisubstituted pyrroles 140 in yields of 90-95\% (Scheme 44) [63].

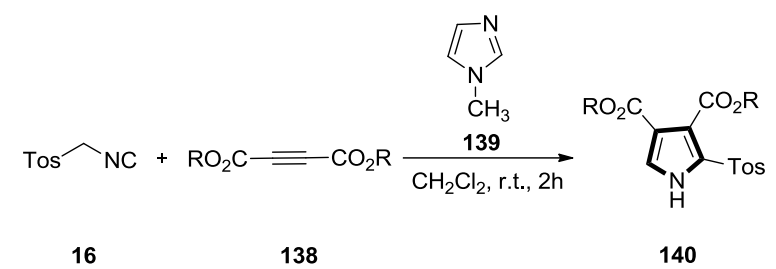

Scheme 44. Synthesis of 2,3,4-trisubstituted pyrrole derivatives 140.

\section{Conclusions}

In summary, the Van Leusen [3+2] cycloaddition reaction based on TosMICs and electron-deficient compounds is involved in the construction of pyrrole and its derivatives because of its advantages such as simple and convenient synthesis substrate, diverse products, etc., and will play an increasingly important role in the synthesis of bioactive pyrrole derivatives in the pharmaceutical synthesis. In recent years, some research progress has been made, which provides new ideas for the synthesis of polysubstituted pyrrole ring framework. In the future, there will be a focus on developing more types and higher selectivity 2-carbon synthons in subsequent research to increase the expansion of the reaction.

Author Contributions: All authors wrote the paper. All authors read and approved the final manuscript.

Funding: Financial support of this research provided by Science and Technology Planning Project of Jilin Province $(20160414015 \mathrm{GH})$ is greatly acknowledged.

Conflicts of Interest: The authors declare no conflict of interest.

\section{References}

1. Idhayadhulla, A.; Kumar, R.S.; Nasser, A.J.A. Synthesis, Characterization and Antimicrobial Activity of New Pyrrole Derivatives. J. Mex. Chem. Soc. 2011, 55, 218-223. 
2. Massa, S.; Artico, M.; Corelli, F.; Mai, A.; Di Santo, R.; Cortes, S.; Marongiu, M.E.; Pani, A.; La Colla, P. Synthesis and Antimicrobial and Cytotoxic Activities of Pyrrole-Containing Analogues of Trichostatin A. J. Med. Chem. 1990, 33, 2845-2849. [CrossRef] [PubMed]

3. Gordee, R.S.; Matthews, T.R. Systemic Antifungal Activity of Pyrrolnitrini. Appl. Microbiol. 1969, 17, 690-694. [PubMed]

4. Di Santo, R.; Tafi, A.; Costi, R.; Botta, N.; Artico, M.; Corelli, F.; Forte, M.; Caporuscio, F.; Angiolella, L.; Palamara, A.T. Antifungal Agents. 11. N-Substituted Derivatives of 1-[(Aryl)(4-aryl- $1 H_{-}$ pyrrol-3-yl)methyl]-1H-imidazole: Synthesis, Anti-Candida Activity, and QSAR Studies. J. Med. Chem. 2005, 48, 5140-5153. [CrossRef] [PubMed]

5. Hyneck, M.L.; Smitch, P.C.; Munafo, A.; Mcdonagh, A.F.; Benet, L.Z. Disposition and irreversible plasma protein binding of tolmetin in humans. Clin. Pharmacol. Ther. 1988, 44, 107-114. [CrossRef] [PubMed]

6. Wilkerson, W.W.; Copeland, R.A.; Covington, M.; Trzaskos, J.M. Antiinflammatory 4,5-Diarylpyrroles. 2. Activity as a Function of Cyclooxygenase-2 Inhibition. J. Med. Chem. 1995, 38, 3895-3901. [CrossRef] [PubMed]

7. Jiang, S.B.; Lu, H.; Liu, S.W.; Zhao, Q.; He, Y.X.; Debnath, A.K. N-Substituted Pyrrole Derivatives as Novel Human Immunodeficiency Virus Type 1 Entry Inhibitors That Interfere with the gp41 Six-Helix Bundle Formation and Block Virus Fusion. Antimicrob. Agents Chemother. 2004, 48, 4349-4359. [CrossRef] [PubMed]

8. Okanya, P.W.; Mohr, K.I.; Gerth, K.; Jansen, R.; Müller, R. Marinoquinolines A-F, Pyrroloquinolines from Ohtaekwangia kribbensis (Bacteroidetes). J. Nat. Prod. 2011, 74, 603-608. [CrossRef] [PubMed]

9. Lee, H.; Lee, J.; Lee, S.K.; Shin, Y.; Jung, W.; Kim, J.H.; Park, K.; Kim, K.; Cho, H.S.; Ro, S.; et al. A Novel Class of Highly Potent, Selective, and Non-Peptidic Inhibitor of Ras Farnesyltransferase (FTase). Bioorg. Med. Chem. Lett. 2001, 11, 3069-3072. [CrossRef]

10. Paludetto, M.N.; Bijani, C.; Puisset, F.; Bernardes-Génisson, V.; Arellano, C.; Robert, A. MetalloporphyrinCatalyzed Oxidation of Sunitinib and Pazopanib, Two Anticancer Tyrosine Kinase Inhibitors: Evidence for New Potentially Toxic Metabolites. J. Med. Chem. 2018, 61, 7849-7860. [CrossRef] [PubMed]

11. Scala, F.; Fattorusso, E.; Menna, M.; Taglialatela-Scafati, O.; Tierney, M.; Kaiser, M.; Tasdemir, D. Bromopyrrole Alkaloids as Lead Compounds against Protozoan Parasites. Mar. Drugs 2010, 8, 2162-2174. [CrossRef] [PubMed]

12. Ragno, R.; Simeoni, S.; Rotili, D.; Caroli, A.; Botta, G.; Brosch, G.; Massa, S.; Mai, A. Class II-selective histone deacetylase inhibitors. Part 2: Alignment-independent GRIND 3-D QSAR, homology and docking studies. Eur. J. Med. Chem. 2008, 43, 621-632. [CrossRef] [PubMed]

13. Di Sanro, R.; Tafi, A.; Costi, R.; Artico, M.; Miele, G.; Lavecchia, A.; Novellino, E.; Bergamini, A.; Cancio, R.; Maga, G. Arylthiopyrrole (AThP) Derivatives as Non-Nucleoside HIV-1 Reverse Transcriptase Inhibitors: Synthesis, Structure-Activity Relationships, and Docking Studies (Part 1). Chem. Med. Chem. 2006, 1, 1367-1378. [CrossRef] [PubMed]

14. Ono, N.; Okujima, T. Synthesis of Pyrroles and Their Derivatives from Isocyanides. In Isocyanide Chemistry, 1st ed.; Nenajdenko, V.G., Ed.; Wiley-VCH: Weinheim, Germany, 2012; pp. 385-429.

15. Knorr, L. Synthese von Pyrrolderivaten. Ber. Dtsch. Chem. Ges. 1884, 17, 1635-1642.

16. Paal, C. Synthese von Thiophen- und Pyrrolderivaten. Ber. Dtsch. Chem. Ges. 1885, 18, 367-371. [CrossRef]

17. Hantzsch, A. Neue Bildungsweise von Pyrrolderivaten. Ber. Dtsch. Chem. Ges. 1890, 23, 1474-1476. [CrossRef]

18. Barton, D.H.R.; Kervagoret, J.; Zard, S.Z. A useful synthesis of pyrroles from nitroolefins. Tetrahedron 1990, 46, 7587-7598. [CrossRef]

19. Van leusen, A.M.; Siderius, H.; Hoogenboom, B.E.; Van Leusen, D. A new and simple synthesis of the pyrrole ring system from Michael acceptors and tosylmethylisocyanides. Tetrahedron Lett. 1972, 13, 5337-5340. [CrossRef]

20. Milgram, B.C.; Eskildsen, K.; Richter, S.M.; Scheidt, W.R.; Scheidt, K.A. Microwave-Assisted Piloty-Robinson Synthesis of 3,4-Disubstituted Pyrroles. J. Org. Chem. 2007, 72, 3941-3944. [CrossRef] [PubMed]

21. Moskal, J.; Van Leusen, A.M. A New Synthesis of Indoles by Electrocyclic Ring Closure of Dialkenylpyrroles. Synthesis of Alkenylpyrroles from 1-Tosylalkenyl Isocyanides and Michael Acceptors. J. Org. Chem. 1986, 51, 4131-4139. [CrossRef]

22. Ten Have, R.; Leusink, F.R.; Van Leusen, A.M. An Efficient Synthesis of Substituted 3(4)-Nitropyrroles from Nitroalkenes and Tosylmethyl Isocyanides. Synthesis 1996, 7, 871-876. [CrossRef] 
23. Tandon, V.K.; Rai, S. p-Toluenesulfonylmethyl isocyanide: A versatile synthon in organic chemistry. Sulfur Rep. 2003, 24, 307-385.

24. Dijkstra, H.P.; Ten Have, R.; Van Leusen, A.M. A Direct Synthesis of 2-(Trimethylstannyl)pyrroles from Michael Acceptors and Stannylated Tosylmethyl Isocyanide. J. Org. Chem. 1998, 63, 5332-5338. [CrossRef]

25. Pavri, N.P.; Trudell, M.L. An Efficient Method for the Synthesis of 3-Arylpyrroles. J. Org. Chem. 1997, 62, 2649-2651. [CrossRef] [PubMed]

26. Di Santo, R.; Costi, R.; Massa, S.; Artico, M. Pyrrole-Annulated Heterocyclic Systems. Synthesis of 2H-Pyrrolo[3,4-b][1,5]benzothiazepine 4,4-Dioxide Derivatives. Synth. Commun. 1998, 28, 2517-2530. [CrossRef]

27. Krishna, P.R.; Ramana Reddy, V.V.; Srinivas, R. A new synthetic route to oxazole and pyrrole 2-deoxy-C-ribosides. Tetrahedron 2007, 63, 9871-9880. [CrossRef]

28. Chang, J.H.; Shin, H. Practical One-Pot Syntheses of Ethyl 4-Substituted-1H-Pyrrole-3-Carboxylates from Aldehydes. Org. Process Res. Dev. 2008, 12, 291-293. [CrossRef]

29. Zhu, R.; Xing, L.X.; Liu, Y.T.; Deng, F.K.; Wang, X.Y.; Hu, Y.F. Practical one-pot sequential procedure for the preparation of $\mathrm{N}$-arylated 3,4-disubstituted pyrroles from alkenes. J. Organomet. Chem. 2008, 693, 3897-3901. [CrossRef]

30. Poulard, C.; Cornet, J.; Legoupy, S.; Dujardin, G.; Dhal, R.; Huet, F. Synthesis of Polysubstituted Pyrroles. Lett. Org. Chem. 2009, 6, 359-361. [CrossRef]

31. Sánchez-García, D.; Borrell, J.I.; Nonell, S. One-Pot Synthesis of Substituted 2,2'-Bipyrroles. A Straightforward Route to Aryl Porphycenes. Org. Lett. 2009, 11, 77-79. [CrossRef] [PubMed]

32. Furlotti, G.; Alisi, M.A.; Apicella, C.; de Joannon, A.C.; Cazzolla, N.; Costi, R.; Crucitti, G.C.; Garrone, B.; Iacovo, A.; Magarò, G.; et al. Discovery and Pharmacological Profile of New $1 H$-Indazole-3-carboxamide and $2 \mathrm{H}$-Pyrrolo[3,4-c]quinoline Derivatives as Selective Serotonin 4 Receptor Ligands. J. Med. Chem. 2012, 55, 9446-9466. [CrossRef] [PubMed]

33. Lu, X.M.; Li, J.; Cai, Z.J.; Wang, R.; Wang, S.Y.; Ji, S.J. One pot synthesis of pyrrolo[3,4-c]quinolinone/ pyrrolo[3,4-c]quinoline derivatives from 2-aminoarylacrylates/2-aminochalcones and tosylmethyl isocyanide (TosMIC). Org. Biomol. Chem. 2014, 12, 9471-9477. [CrossRef] [PubMed]

34. Zhang, X.; Feng, C.J.; Jiang, T.; Li, Y.F.; Pan, L.; Xu, X.X. Expedient and Divergent Tandem One-Pot Synthesis of Benz[e]indole and Spiro[indene-1,3'-pyrrole] Derivatives from Alkyne-Tethered Chalcones/Cinnamates and TosMIC. Org. Lett. 2015, 17, 3576-3579. [CrossRef] [PubMed]

35. Walter, H.; Lamberth, C.; Corsi, C. Synthesis of fungicidally active succinate dehydrogenase inhibitors with novel difluoromethylated heterocyclic acid moieties. Monatshefte Chem. 2018, 149, 791-799. [CrossRef]

36. Donohoe, T.J.; Guyo, P.M.; Harji, R.R.; Heiliwell, M. The Birch reduction of 3-substituted pyrroles. Tetrahedron Lett. 1998, 39, 3075-3078. [CrossRef]

37. Padmavathi, V.; Prema kumari, C.; Venkatesh, B.C.; Padmaja, A. Synthesis and antimicrobial activity of amido linked pyrrolyl and pyrazolyl-oxazoles, thiazoles and imidazoles. Eur. J. Med. Chem. 2011, 46, 5317-5326. [CrossRef] [PubMed]

38. Gudi, Y.; Gundala, S.; Venkatapuram, P.; Adivireddy, P.; Chippada, A.R.; Allagadda, R. Synthesis and Antioxidant Activity of a New Class of Pyridinylcarbamoylmethyl Pyrrolyl/Pyrazolylcarboxamides. J. Heterocycl. Chem. 2017, 54, 3498-3509. [CrossRef]

39. Dannhardt, G.; Kiefer, W.; Krämer, G.; Maehrlein, S.; Nowe, U.; Fiebich, B. The pyrrole moiety as a template for COX-1/COX-2 inhibitors. Eur. J. Med. Chem. 2000, 35, 499-510. [CrossRef]

40. Rao, H.S.P.; Sivakumar, S. Aroylketene dithioacetal chemistry: Facile synthesis of 4-aroyl-3-methylsulfanyl2-tosylpyrroles from aroylketene dithioacetals and TosMIC. Beilstein J. Org. Chem. 2007, 3, 31. [PubMed]

41. Terzidis, M.; Tsoleridis, C.A.; Stephanidou-Stephanatou, J. Reaction of chromone-3-carboxaldehydes with TOSMIC: Synthesis of 4-(2-hydroxybenzoyl)pyrroles. Tetrahedron 2007, 63, 7828-7832. [CrossRef]

42. Hormaza, A.; Pérez, O.F.A. Síntesis de una nueva serie de pirroles vía cicloadición. Rev. Soc. Quím. Perú 2009, 75, 12-16.

43. Kelly, J.M.; Leeper, F.J. Synthesis of 3,4-fused cycloalkanopyrroles by 1,3-dipolar cycloaddition. Tetrahedron Lett. 2012, 53, 819-821. [CrossRef]

44. Wang, R.; Wang, S.Y.; Ji, S.J. Chemoselective synthesis of 3H-pyrrolo[2,3-c]quinolin-4(5H)-one derivatives from 3-phenacylideneoxindoles and substituted tosylmethyl isocyanide (TosMIC). Tetrahedron 2013, 69, 10836-10841. [CrossRef] 
45. Wang, R.; Wang, S.Y.; Ji, S.J. Water promoted C-C bond cleavage: Facile synthesis of 3,3-bipyrrole derivatives from dienones and tosylmethyl isocyanide (TosMIC). Org. Biomol. Chem. 2014, 12, 1735-1740. [CrossRef] [PubMed]

46. Zhang, L.J.; Zhang, X.M.; Lu, Z.C.; Zhang, D.W.; Xu, X.X. Accessing benzo[f]indole-4,9-diones via a ring expansion strategy: Silver-catalyzed tandem reaction of tosylmethyl isocyanide (TosMIC) with 2-methyleneindene-1,3-diones. Tetrahedron 2016, 72, 7926-7930. [CrossRef]

47. Zhao, K.; Wang, S.; Zhan, X.Q.; Liu, Z.L.; Mao, Z.M. Synthesis and Anti-tumor Activity of 4-(Methoxyl thienyl)-3-(substituted benzoyl)pyrroles. Chin. J. Org. Chem. 2017, 37, 943-953. [CrossRef]

48. Divakar, M.A.; Shanmugam, S. Live cell imaging of bacterial cells: Pyrenoylpyrrole-based fluorescence labeling. Chem. Biol. Drug Des. 2017, 90, 554-560.

49. Sharma, R.; Kumar, K.; Chouhan, M.; Grover, V.; Nair, V.A. Lithium hydroxide mediated synthesis of 3,4-disubstituted pyrroles. RSC Adv. 2013, 3, 14521-14527. [CrossRef]

50. Kumar, K.; More, S.S.; Goyal, S.; Gangar, M.; Khatik, G.L.; Rawal, R.K.; Nair, V.A. A convenient synthesis of 4-alkyl-3-benzoylpyrroles from $\alpha, \beta$-unsaturated ketones and tosylmethyl isocyanide. Tetrahedron Lett. 2016, 57, 2315-2319. [CrossRef]

51. Dhanalakshmi, P.; Shanmugam, S. Convenient one-pot multicomponent strategy for the synthesis of 6-pyrrolylpyrimidines. RSC Adv. 2014, 4, 29493-29501.

52. Qin, J.; Zhang, J.; Wu, B.; Zheng, Z.G.; Yang, M.; Yu, X.Q. Efficient and Mild Protocol for the Synthesis of 4(3)-Substituted 3(4)-Nitro-1H-pyrroles and 3-Substituted 4-Methyl-2-tosyl-1H-pyrroles from Nitroolefins and Tosylmethyl Isocyanide in Ionic Liquids. Chin. J. Chem. 2009, 27, 1782-1788. [CrossRef]

53. Qiu, F.L.; Wu, J.W.; Zhang, Y.H.; Hu, M.; Yu, F.; Zhang, G.L.; Yu, Y.P. A Novel Synthesis of Multisubstituted Pyrroles via Trisubstituted Olefins and TosMIC Derivatives. Lett. Org. Chem. 2012, 9, 305-308.

54. Qiu, F.L.; Wu, J.W.; Zhang, Y.H.; Hu, M.; Yu, Y.P. One-pot cascade approach to 1,3'-bipyrrole derivatives from trisubstituted olefins with tosylmethyl-isocyanide (TosMIC). Tetrahedron Lett. 2012, 53, 446-448. [CrossRef]

55. Smith, N.D.; Huang, D.; Cosford, N.D.P. One-Step Synthesis of 3-Aryl- and 3,4-Diaryl-(1H)-Pyrroles Using Tosylmethyl Isocyanide (TOSMIC). Org. Lett. 2002, 4, 3537-3539. [CrossRef] [PubMed]

56. Magnus, P.; Gallagher, T.; Schultz, J.; Or, Y.S.; Ananthanarayan, T.P. Studies on the synthesis of the antitumor agent CC-1065. Synthesis of the unprotected cyclopropapyrroloindole A portion using the 3,3'-bipyrrole strategy. J. Am. Chem. Soc. 1987, 109, 2706-2711. [CrossRef]

57. De Leon, C.Y.; Ganem, B. A New Approach to Porphobilinogen and its Analogs. Tetrahedron 1997, 53, 7731-7752. [CrossRef]

58. Di Santo, R.; Costi, R.; Massa, S.; Artico, M. Synthesis of Pyrrolo [3,4-c][1] benzazepine-4,10(2H, 5H)-dione, a Model System Useful for the Design of 11-Oxosibiromycinone Analogues. Synth. Commun. 1996, 26, 1839-1847. [CrossRef]

59. Chen, W.T.; Shao, J.A.; Li, Z.; Giulianotti, M.A.; Yu, Y.P. Synthesis of 2,3,4-trisubstituted pyrroles via a facile reaction of vinyl azides and tosylmethyl isocyanide. Can. J. Chem. 2012, 90, 214-221. [CrossRef]

60. Zhang, X.M.; Xu, X.X.; Zhang, D.W. [3+2] Cycloaddition of Tosylmethyl Isocyanide with Styrylisoxazoles: Facile Access to Polysubstituted (isoxazol-5-yl)pyrroles. Molecules 2017, 22, 1131. [CrossRef] [PubMed]

61. Saikachi, H.; Kitagawa, T.; Sasaki, H. Reaction of Tosylmethyl Isocyanide with Methyl 3-Substituted Propiolates as Acetylenic Michael Acceptors. Chem. Pharm. Bull. 1979, 27, 2857-2861. [CrossRef]

62. Alizadeh, A.; Masrouri, H.; Rostamnia, S.; Movahedi, F. One-Step Synthesis of Dialkyl 2-[(4-Methylphenyl)sulfonyl]-1H-pyrrole-3,4-dicarboxylates by Reaction of Acetylenedicarboxylates with 'Tosylmethyl Isocyanide' (TsMIC) and Triphenylphosphine. Helv. Chim. Acta 2006, 89, 923-926. [CrossRef]

63. Adib, M.; Mohammadi, B.; Sheikhi, E.; Bijanzadeh, H.R. 1-Methylimidazole-catalyzed reaction between tosylmethyl isocyanide and dialkyl acetylenedicarboxylates: An efficient synthesis of functionalized pyrroles. Chin. Chem. Lett. 2011, 22, 314-317. [CrossRef]

(C) 2018 by the authors. Licensee MDPI, Basel, Switzerland. This article is an open access article distributed under the terms and conditions of the Creative Commons Attribution (CC BY) license (http:/ / creativecommons.org/licenses/by/4.0/). 